\title{
MEASURMENET OF INFLATION FORECAST TARGETING. A PROPOSAL OF METHODOLOGICAL SOLUTION
}

\author{
Magdalena Szyszko
}

\section{Introduction}

Modern monetary policy focuses on inflation expectations. It is consistent with modern monetary theory: new neoclassical synthesis (NNS). NNS gives the background of monetary transmission mechanism. New Keynesian Phillips Curve, IS curve (production equation) as well as central bank's reaction function include economic agents' expectations. The NNS and its implications for monetary policy are broadly described in the literature (Goodfriend \& King, 1997; Galí, 2008; Woodford, 2003). Central bankers are continuously searching for the tools that would enhance their opportunity to influence inflation expectations. Inflation targeting (IT) framework of monetary policy is an optimal solution for the central bank's functioning within the frames of NNS. IT constitutes various possibilities for shaping expectations of the public that is focusing on numerically set inflation target, producing and publishing inflation forecast, setting floating exchange rate regime, and, finally, ensuring central bank's independence and transparency. Possibility of shaping inflation expectations in the frameworks of IT is confirmed in theoretical (Eusepi \& Preston, 2010) and empirical research (Strohsal \& Winkelman, 2015). However there are also research questioning such it (Kumar et al., 2015). Regardless some papers suggesting the central bank's ineffectiveness in shaping expectations, IT is perceived as the best way of implementing modern monetary policy.

One argues that the central bank's inflation forecast is one of the most important tools of supporting inflation expectations (Skořepa \& Kotlán, 2003). Empirical research proves that there are interdependences between inflation forecast and inflation expectations (Szyszko, 2015). Other research (i.e. BrzozaBrzezina \& Kot, 2008; Geraats, 2009; Faust \& Svensson, 2001) confirms the impact of the forecast publication on the economy and its performance as well as on the central bank's ability to achieve its goals. The forecast also supports the Monetary Policy Committee (MPC) decision-making process. It offers at least concise framework for policy analysis but it can be even intermediate target for monetary policy.

The context of the central bank's inflation forecast is, however, quite complicated. It covers methodology of forecasting, the way in which the forecast is published and a possible impact of the forecast result on the central bank's decision on the interest rates. The forecast of inflation may even become intermediate target of monetary policy when the central bank implements inflation forecast targeting (IFT). There is wide research into the field of possible use of inflation forecast in monetary policy (presented in next section). The central banks' practice here also varies substantially.

The following paper is of methodological nature and it introduces the inflation forecast targeting index (hereafter: IFT index). It has been designed to measure IFT implementation. Verification of various hypotheses on the existence of the relation between the IFT and other aspects of monetary policy with the use of such index is possible. The IFT index gives also a concise framework of practical aspects of IFT. Such an index has not been presented in the literature up to now. The elaboration of IFT index is thus the main purpose of the following paper. Another goal is to discuss its possible implementations in the research as the index opens the possibility to further research on forecast usefulness in monetary policy.

One may ask a question at this point: the question on the validity of qualitative aspects measurement. The arguments in favor of such a measurement refer to the inflation forecast 
importance for monetary policy, both in the decision making process and communication. This measurement makes it possible to draw profound conclusions on the relations and causality. It also opens the field for territorial and over-time comparison of the central banks' practice. That is why the literature gives numerous examples of qualitative aspects measures.

The following paper is divided into four sections. The first one presents the literature overview of the inflation forecast targeting, which is the basis for designing the IFT aspects. It also highlights the importance of inflation forecast for a modern central bank. The second section presents details on measuring transparency of the central bank. The literature in this case gives some solutions to the accepted ways of qualitative aspects measurement, including transparency. The third section is of methodological nature and it describes the tool (IFT index). The last section is on possible index implementation in empirical research.

The paper contributes to the literature on inflation forecast targeting and broadly on inflation targeting strategy. It also contributes to the discussion on measurement of qualitative aspects of monetary policy.

\section{Inflation Forecast Targeting: Literature Review}

The inflation forecast is an immanent part of a fully-fledged inflation targeting. A central bank produces its own forecasts, uses them in the decision-making process and reveals them to the public. Inflation targeting, which is perceived to be the best monetary policy strategy by the consensus of NNS, may become inflation forecast targeting (IFT), where inflation forecast is an intermediate objective of monetary policy. It is by definition a current variable which is the most correlated with the final goal, it is more controllable than the final goal, and it can be made more observable. It can also be made very transparent and facilitate the central bank's communication with the public (Debelle, 1997). Moreover, inflation forecast integrates a broad set of historical and current data as well as the expectations. It means that one variable - the forecast - includes the idea of analyzing various data, simultaneously giving the simplicity of following an intermediate target commitment. One argues that subscribing the function of an intermediate target to the inflation forecast simplifies both implementing and monitoring monetary policy (Svensson, 1997). The idea of IFT has been broadly described in the literature. The main threads of this discussion are presented below.

The central bank's inflation forecast for the period of inflation forecast targeting horizon becomes an intermediate target. Hence the instrument should be set so as to make the inflation forecast equal to the inflation target. Following this rule is claimed to be the best central bank's practice. Ex post inflation may differ from the targeted level because of forecast errors (Svensson, 1996). The decision-making procedure of IFT is repeated by the monetary committee at any decision meeting. The forecasts and interest rate level are brought up to date if it is necessary. That is why IFT becomes a dynamic optimization procedure (Szyszko, 2013). The inflation forecast may become the input to the decisionmaking process of the central bank, even when the forecast is not published (implicit IFT). Revealing inflation forecast makes it possible to fulfill the external forecast function: the explanatory one - regarding the decision that has just been made and enhancing the central banks' ability to influence economic agents' expectations. This broader approach to IFT constitutes a concise framework for both the decision and its communication. That is why from the practical point of view, inflation forecast targeting encompasses two aspects (Fig. 1).

Inflation forecast targeting may also be perceived as a monetary policy rule (Woodford, 2012). As a rule, the IFT makes the decision making process more systematic and concise. It also facilitates the introduction of new members into decision-making body. Declaration on IFT implementation limits the possibility to influence the central banks' decision as such an influence, if in contradiction with the rule, can be easily captured by the public. Finally, any monetary policy rule makes the MPC decisions anticipation easier, which supports expectations formation.

The central bank may produce the inflation forecast under the assumption of constant central bank's rates (CIR) and the central bank's interest rates consistent with market expectations (ME). Such a forecast is called conditional (projection). Alternative option is interest rates endogenisation (unconditional 


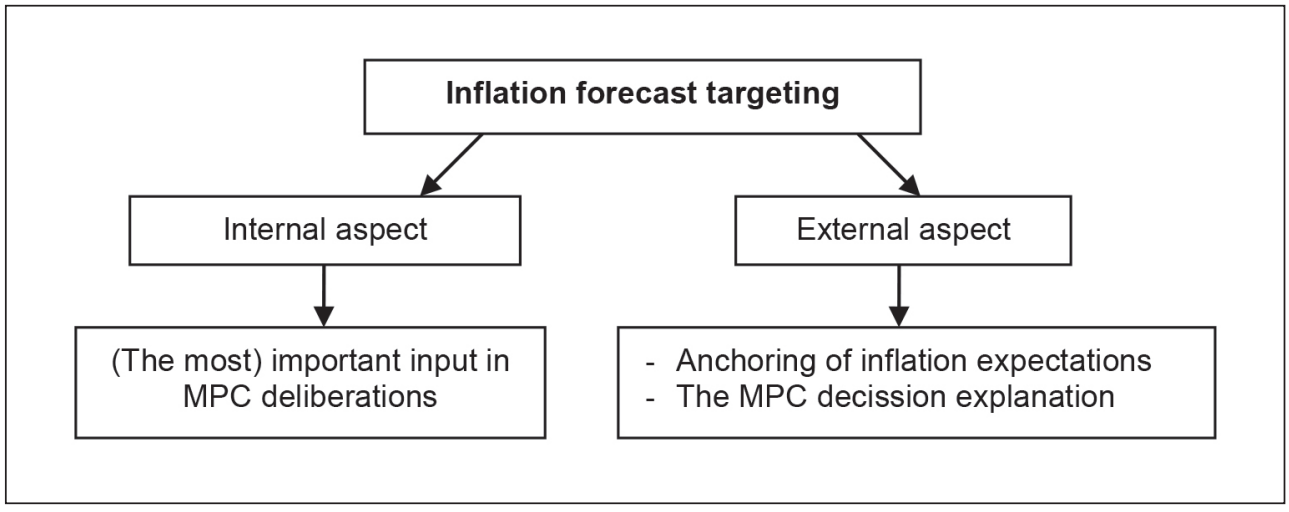

Source: own

forecast). Forecasting methodology has been evolving over time from constant rate assumption to unconditional forecast. It is embodied in the discussion on the optimal level of the central bank's transparency and the way of signaling its intentions. Producing and revealing policy path - the central bank's interest rates consistent with the forecast is the next frontier in the central bank's transparency. Overruling the assumption on the constant central bank's rates brings the necessity to elaborate the MPC reaction function. It is mostly in line with the Taylor Rule which is an instrument rule. Its genuine specifications determine the changes of the central bank's interest rates as the result of the actual inflation deviation from the inflation target (inflation gap) and the deviation of the product from its potential level (output gap) (Taylor, 1993). Modern specification refers to inflation forecast or inflation expectations instead of actual inflation, which makes the rule forward-looking. The other possibility is a specific targeting rule which specifies condition for the forecasts of the target variables (inflation and output). The policy path should be set to ensure the equality of the marginal rates of transformation of the combination of outputgap forecast into the two-period-ahead inflation forecast and the marginal rates of substitution of inflation in period $t+j$, for the output gap in period $t+k$. Then, the monetary-policy problem consists of finding the combination of forecasts and instrument path consistent with the central bank's forecasting model (Svensson, 2003),
(Woodford, 2013). The specific targeting rule is used in the Bank of Sweden. Regardless of the severe criticism, the Taylor Rule or similar specifications of reaction functions are more often used by the central banks.

The discussion on revealing a policy path, especially in a numerical way (on the fan chart usually) is still quite vivid. Only several central banks do so, that is central banks of: The Czech Republic, New Zealand, Israel, Norway, and Sweden.

Decision making rule depends on the way how the central banks' interest rates are captured by the economic model. However, the starting point is the same: the instrument should be set to stabilize inflation on the targeted level in the monetary policy horizon (Leitemo, 2006). The simplest version is just a rule of thumb applicable to conditional forecasts: if the inflation target is above (below) the target within the monetary policy horizon, the main rate of the monetary policy should be raised (lowered). If the central path of inflation in the monetary policy horizon is on the targeted level - no interest rates change is required. This is how the IFT was described in the earliest literature on the subject (Svensson, 1997). When the forecast is produced, the central bank makes a decision on the next change of the interest rates and nothing else. It is conceptually easier than giving the whole path of interest rates. This approach is still used by the central banks producing conditional forecasts. However, a more developed rule requires optimal policy 
path for the entire forecast horizon. It is possible, in the way consistent with the model, only with the interest rates endogenisation. Moreover, the MPC may discuss several interest paths for one forecast. It chooses the one that in its opinion is the best solution from inflation (and output) stabilization point of view (Svensson, 1999). When the policy path for a longer horizon is produced, the central bank's decision in line with the forecast means following the path. As it is relatively easily when the forecast is up to date, the policy paths for longer term is not obeyed. There is empirical research which confirms that the forecasts of interest rates had little or no informational value when the horizon exceeded two quarters (six months), although they were good in the next quarter and reasonable in the following one (Goodhart \& Bin Lim, 2011). The reasons are obvious: in time the forecast and the policy path itself become stale. A new forecast with a new solution on interest rates appears. The central bank's decision procedures are not designed to make decisions on interest rates for subsequent periods as well.

The discussion on the central bank's transparency and its optimal level means nowadays deliberations on central bank's forecast relevance as well as publishing other information connected with forecasting procedures (assumptions, model, errors, risk assessment, policy path). Transparency is beneficial when it serves to simplify communication with the public and helps generate support for central banks to conduct the monetary policy optimally with an appropriate focus on the long-run objectives. However, it can complicate the communication process and weaken support for a central bank focus on the long-run objectives (Mishkin, 2004). The optimal level of transparency cannot be easily determined. The theoretical discussion on this issue is still in progress. The central banks' practices in this field are not unique and their choices are justified differently. However, the transparency level of the monetary policy is largely aligned. The public knows the main goal, instruments and main premises of the decision making process, including forecasts. Moreover, the monetary authority explains the decision which has just been made. The differences are mainly connected with the intentions of future actions demonstration.

The point of view presented in the paper is as follows: the more information on the forecast revealed, the better. This is institutional approach to transparency (Winkler, 2000). The understanding of the information is not examined. Focus on institutional transparency is commonly used in the research.

\section{Measuring Transparency of Monetary Policy: Literature Review}

Asection on the transparency measurementoffers a brief explanation of the need and the ways of such a measurement. Inflation forecast targeting is also a qualitative procedure. It is related to the central bank's transparency which is one of the institutional (qualitative) aspects of modern monetary policy together with independence, accountability and credibility. As transparency is of qualitative nature and is not directly observed, the problem of the measurement appeared here. Descriptive analyses are not enough as they are

\section{Fig. 2: Measurement of qualitative aspects of monetary policy}

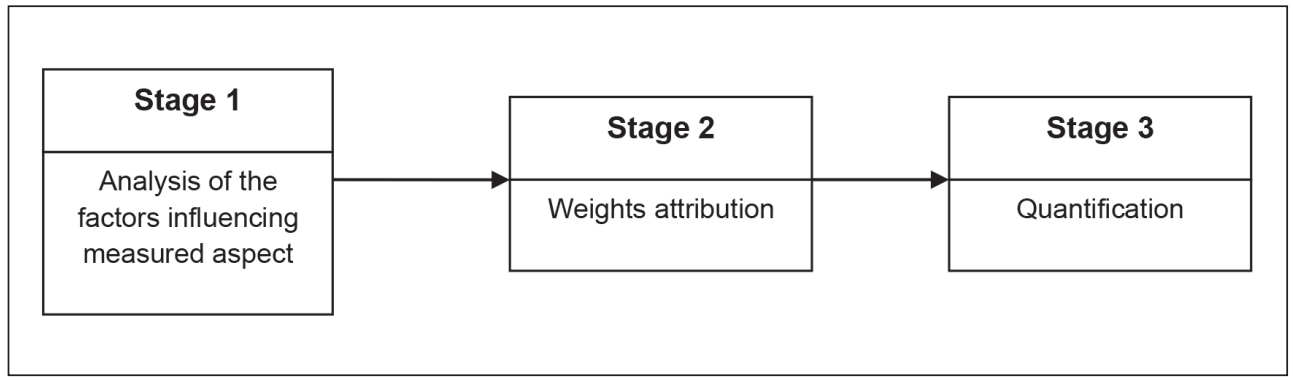


not sufficient for developed research, finding interdependences and causalities. Elaboration of the qualitative aspect measure facilitates the analysis of the relations between the level of their implementation and the central bank's effectiveness or the economic performance. That is why, regardless of the reproaches of non-objectivity, measures of qualitative aspects are described in the literature and used in the research.

\section{Tab. 1: Transparency measures - the examples}

\begin{tabular}{|c|c|c|}
\hline Authors & Factors coverage & Comment \\
\hline Fy et al. (2000) & $\begin{array}{l}\text { - prompt public explanation of policy } \\
\text { decision, } \\
\text { - frequency and form of forward-looking } \\
\text { analysis provided to the public, } \\
\text { - frequency of bulletins, research } \\
\text { papers, speeches }\end{array}$ & $\begin{array}{l}\text { Quite narrow approach to } \\
\text { transparency. First approach to the } \\
\text { measurement in the literature. }\end{array}$ \\
\hline $\begin{array}{l}\text { Bini-Smaghi \& } \\
\text { Gros (2001) }\end{array}$ & $\begin{array}{l}\text { - } \quad \text { objectives, } \\
\text { - } \quad \text { strategy, } \\
\text { - } \quad \text { communication of data and forecasts, }\end{array}$ & $\begin{array}{l}\text { Analysis of transparency and } \\
\text { accountability. }\end{array}$ \\
\hline $\begin{array}{l}\text { Fracasso, } \\
\text { Genberg, \& } \\
\text { Wyplosz (2003) }\end{array}$ & $\begin{array}{l}\text { - } \quad \text { assumptions about key } \\
\text { macroeconomic variables, } \\
\text { - } \quad \text { the presentation of the policy-making } \\
\text { process, } \\
\text { - } \quad \text { the executive summary; } \\
\text { expertise, completeness, writing style } \\
\text { and information }\end{array}$ & $\begin{array}{l}\text { On the basis of Inflation Reports } \\
\text { analysis; the authors delivered an } \\
\text { overall rating of Inflation Reports; } \\
\text { quantity, quality and accessibility of } \\
\text { information is assessed. }\end{array}$ \\
\hline $\begin{array}{l}\text { Eijffinger \& } \\
\text { Geraats (2006) }\end{array}$ & 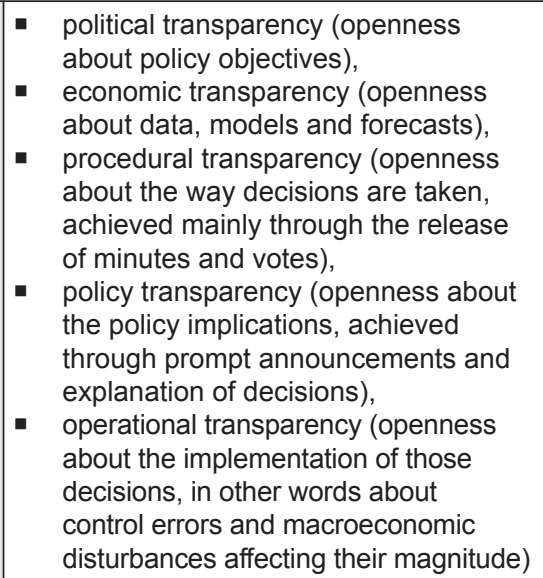 & $\begin{array}{l}\text { This approach is frequently used in } \\
\text { the literature (Dincer \& Eichengreen, } \\
\text { 2007), (Siklos, 2010) to cross- } \\
\text { country and over-time comparison. } \\
\text { Geraats taxonomy for transparency } \\
\text { analysis was its background } \\
\text { (Geraats, 2001). This measure is } \\
\text { popular due to wide coverage of } \\
\text { different aspects of transparency, } \\
\text { consistency with inflation targeting } \\
\text { and detailed description of the } \\
\text { points attribution, which facilitates } \\
\text { measurement. It is also inspiration for } \\
\text { other measurements (Bajalan Raei, } \\
\text { \& Tehrani, 2012) and the basis for } \\
\text { regression analysis (Crowe \& Meade, } \\
\text { 2008), (Dincer \& Eichengreen, 2014). }\end{array}$ \\
\hline $\begin{array}{l}\text { Bajalan, Raei, } \\
\text { \&Tehrani (2012) }\end{array}$ & $\begin{array}{l}\text { - } \text { openness of the policy (based at the } \\
\text { Eijffinger-Geraats index), } \\
\text { clarity referring to presentation and } \\
\text { analysis of information, } \\
\text { - } \\
\text { honesty referring to the intentions of } \\
\text { the information sender, } \\
\text { common understanding referring to } \\
\text { the linguistic code of both, the sender } \\
\text { and receiver. }\end{array}$ & $\begin{array}{l}\text { More developed conceptual } \\
\text { framework of the index. It tries to } \\
\text { capture the possible gap between } \\
\text { intentions of the sender and } \\
\text { understanding of the information by } \\
\text { the receiver. }\end{array}$ \\
\hline
\end{tabular}


The way how the measurement is conducted is similar regardless of the authorship of the measure (Fig. 2). It starts with the identification of the factors that influence the measure. The empirical and theoretical research gives a background of such an analysis. Usually a broad set of factors is enumerated here. It makes it possible to capture the changes more exactly in comparison with a simple one to one identification. Then, the weights are attributed. Finally, the measurement itself takes place. Tab. 1 presents several examples of such measures.

IFT procedure is connected with the central banks' transparency in the field of revealing forecasting methods, decision-making procedures, decisions explanations and signaling central bank's intentions. This is why Tab. 1 presents several transparency measures. They refer to general transparency. They are all survey based measures - a questionnaire with factors affecting the transparency is used to quantify the level of transparency. Alternative measures of transparency refer to the market data: if the monetary policy is transparent, the news on central banks actions drive to less remarkable shifts in yields curves. This kind of measurement refers also to the central banks' news understanding. Standard measures do not capture understanding.

Transparency measures differs with the authors' different point of view and the goal of the research. This subjectivity is most remarkable reproach to qualitative aspects measurement. Not the only one. It is also difficult to describe precisely whet the points should be attributed. For example, one of the questions in Eijffinger-Geraats index is: Does the central bank regularly provide an evaluation of the policy outcome in light of its macroeconomic objectives? And the $1 / 2$ point answer is: yes, but superficially.

The qualitative indices are also not resistant to the changes. When Fry et al. (2000) index was developed there was no discussion on revealing the central banks' policy path. Nowadays the transparency on the field of goals is quite obvious. The discussion on the optimal transparency focuses on the central bank's intentions. Inflation forecast and IFT is in the center of the debate on optimal decision rules and communication of future actions. In the literature, there is no complex measure of IFT implementation to capture and compare it.

However, there is a proposal of measuring transparency of inflation forecast with a Guttman scale. Guttman scale makes it possible to discover intensity structure between several aspects (features, statement describing a variable). It is commonly used in sociological research. The starting point in scale elaboration is an assumption that a respondent that accepts advanced level (or aspect) of variable accepts the lower one as well. The scale offers

\section{Fig. 3: Guttman scale for transparency of forecasting system}

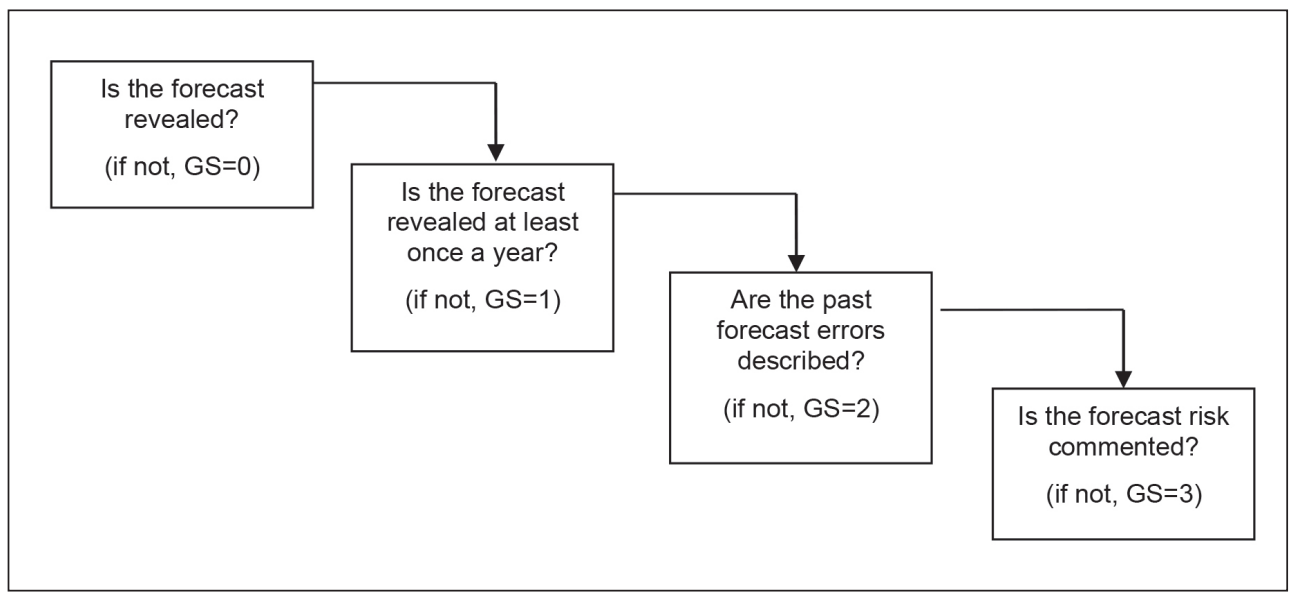


hierarchic arrangement of the variable' features. It is monotonic which means that the probability of accepting a statement on the scale is higher than accepting subsequent statement and lower than accepting the previous one. The scale organizes the features in such a sequence, that acceptance of a statement at any level means the acceptance of any statements which are on upper levels. The example of Guttman scale for transparency of inflation forecast is presented in Fig. 3.

The scale may be modified and enlarged with respect to its monotonic character. Main reproach to this measure is that forecasting procedures and the way how the forecast is published do not impose any hierarchy. The central bank may publish any element of forecasting system except the forecast. Capturing the sequence of the element is not necessary and may be binding. IFT elaborated in the following section offers alternative approach to measuring IFT, conceptually closer to monetary policy transparency measures.

\section{IFT Index - Conceptual Frameworks}

The IFT index elaborated here distinguishes 5 aspects of IFT. They are presented in Fig. 4. While designing the components of IFT, it was assumed that IFT means several aspects of revealing the forecast as well as using the forecast as the input into MPC deliberations. That is why the aspects cover:

- forecasting methodology: including model that reveals the framework of the MPC analysis as it describes transmission mechanism of the monetary policy, and information on the assumptions for the cutoff day of the forecast; producing the forecast is the first step in IFT implementation;

- declaration: just prior to publishing the first forecast (usually in the same document), the central bank should inform the markets what is the role of the forecast in the monetary policy; public announcement opens the field for treating the forecast as the intermediate target;

- publication: to shape inflation expectations or to become intermediate target (for the MPC and under the public control) the forecast should be revealed; the regularity of the publication and its higher frequency enhance the possibility to influence expectations; it also means that the central banker has the most up to date forecast possible; the way how the forecast is published (central path of inflation alone or with the policy path) depends on the central banks' interest rate endogenisation and the central bank's will to reveal its next possible steps;

- actual practice: crucial aspect of IFT, it checks the central bank's decisions consistency with the inflation forecast, in other words, it verifies whether the rule is actually implemented, the way how the decision compatibility with the forecast is checked is described in Fig. 5 and 6; this aspect covers also decision timing - the analysis whether the central bank takes

\section{Fig. 4: IFT index aspects}

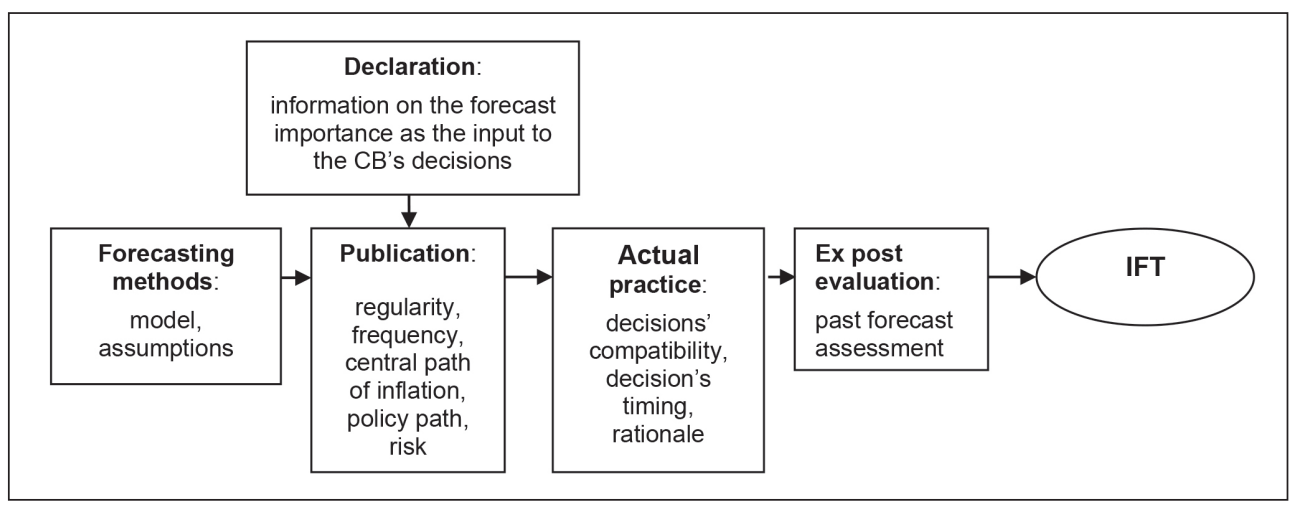




\section{Fig. 5: The MPC's decisions compatibility for conditional forecast}

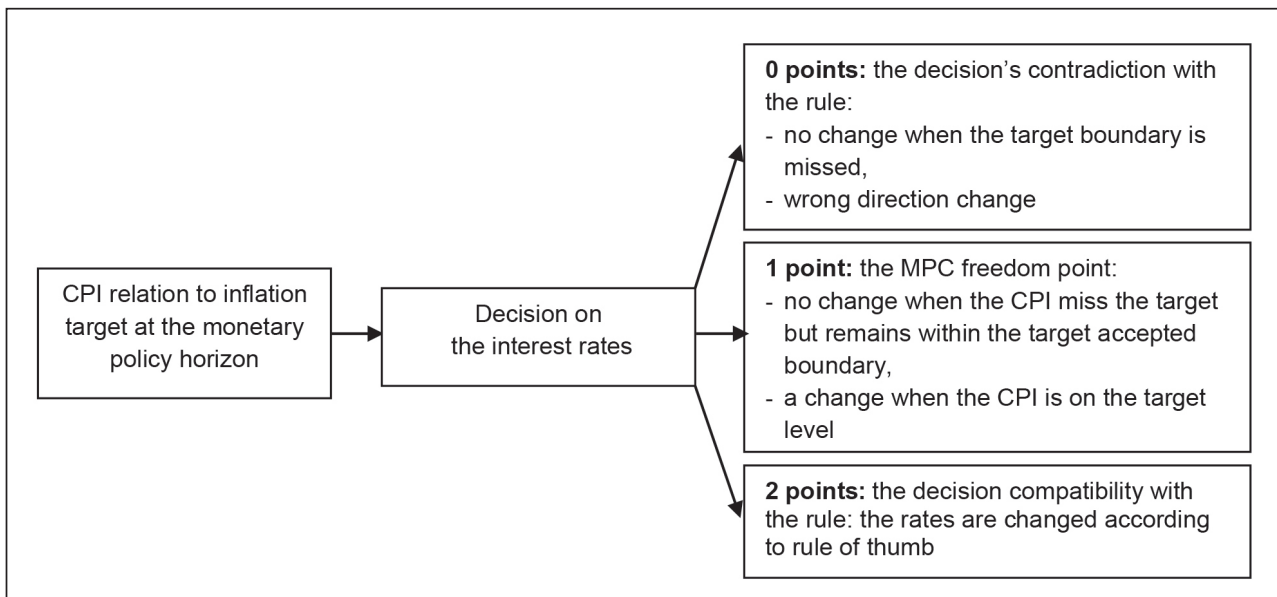

Source: own

Note: CPI - central path of inflation - the most probable inflation level during the forecast horizon

\section{Fig. 6: The MPC's decisions compatibility for unconditional forecast}

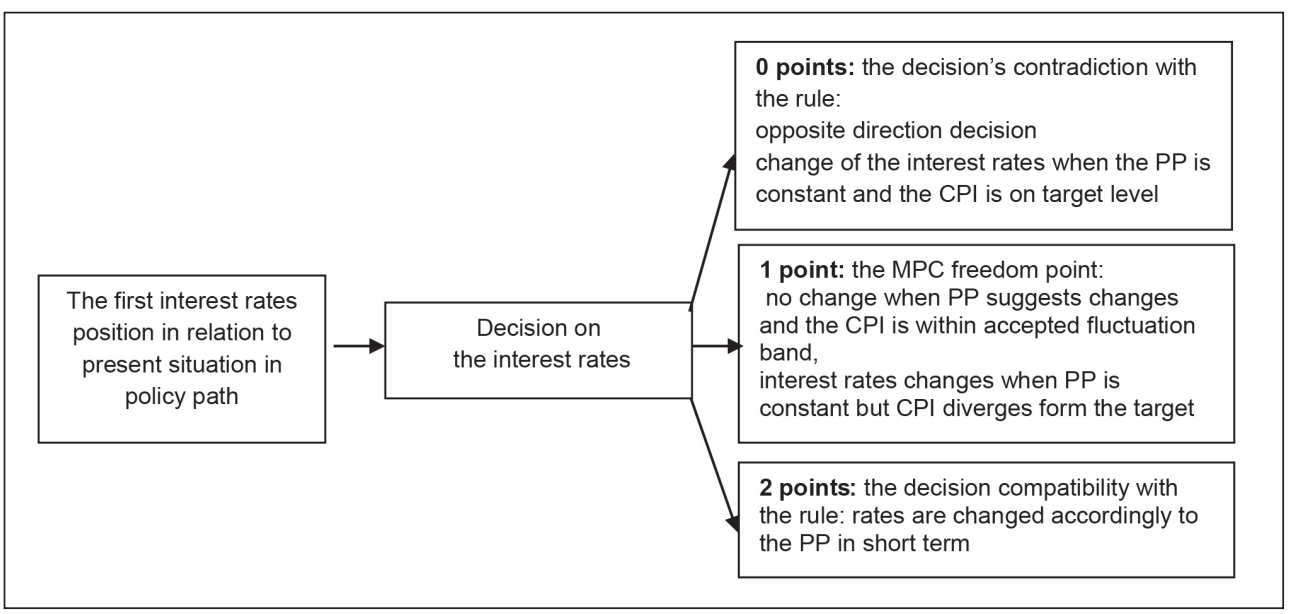

Source: own

Note: $\mathrm{CPI}$ - central path of inflation - the most probable inflation level during the forecast horizon $\mathrm{PP}$ - policy path

the wait and see position, and the forecast in decision explanation (press releases, minutes, rationale of the decision);

- ex post evaluation: refers to the past forecasts and may be done either by comparison of the two subsequent forecasts or by ex post forecast errors; it explains why the decision made previously was not optimal (shocks), what happened in the economy between two forecasting rounds 


\section{Tab. 2: IFT index points' attribution rules - Part 1}

\begin{tabular}{|c|c|c|c|}
\hline & Evaluation & Possible options & How to attribute the points \\
\hline \multirow{2}{*}{ 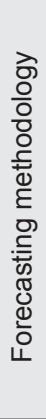 } & $\begin{array}{l}\text { Forecasting } \\
\text { model }\end{array}$ & $\begin{array}{l}0-\text { none } \\
1 / 2-\text { general or partial } \\
\text { description } \\
1-\text { published }\end{array}$ & $\begin{array}{l}\text { Points are attributed for forecasting model's } \\
\text { publication in any central bank's document. } \\
1 \text { point - transmission equations are published } \\
\text { (without parameters). } \\
\text { Actualization when the model's change occurs. } \\
\text { When there are several models employed - the main } \\
\text { medium-term forecasting tool is considered. }\end{array}$ \\
\hline & Assumptions & $\begin{array}{l}0-\text { none } \\
1 / 2-\text { some/different } \\
1-\text { published }\end{array}$ & $\begin{array}{l}0 \text { - there is no information on interest rate assumption. } \\
1 \text { - the central bank publishes also regularly the other } \\
\text { assumptions on exogenous variables. } \\
1 / 2 \text { - the way of presenting assumptions changes over } \\
\text { time. }\end{array}$ \\
\hline \multirow{5}{*}{ 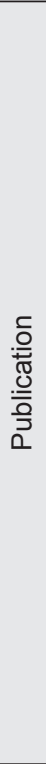 } & Regularity & $\begin{array}{l}0-\text { no } \\
1-\text { yes }\end{array}$ & $\begin{array}{l}1-\text { the same publication schedule in subsequent } \\
\text { years. } \\
\text { If the schedule is changed, point is not attributed } \\
\text { at the first time when the change occurs. }\end{array}$ \\
\hline & Frequency & $\begin{array}{l}0-\text { once a year } \\
1 / 2-2-3 \text { times per year } \\
1-\text { at least quarterly }\end{array}$ & $\begin{array}{l}\text { If the forecast is produced with higher frequency, } \\
\text { the MPC has more up to date input to decision } \\
\text { making deliberations. }\end{array}$ \\
\hline & $\begin{array}{l}\text { Central path } \\
\text { of inflation }\end{array}$ & $\begin{array}{l}0-\text { no } \\
1 \text { - descriptively } \\
2-\text { numerically }\end{array}$ & $\begin{array}{l}\text { The most important information. } \\
\text { Qualitative information refers to the relation of the } \\
\text { forecast in monetary policy horizon to the inflation } \\
\text { target. Quantitative publication of the central path } \\
\text { of inflation (CPI) may be presented on the chart. }\end{array}$ \\
\hline & Policy path & $\begin{array}{l}0-\text { no } \\
1 / 2 \text { - descriptively } \\
1-\text { numerically }\end{array}$ & $\begin{array}{l}\text { Qualitative information: description of the next change } \\
\text { of the interest rates. } \\
\text { Quantitative information: a fan chart with policy path } \\
\text { (PP). }\end{array}$ \\
\hline & Risk analysis & $\begin{array}{l}0-\text { no } \\
1-\text { yes }\end{array}$ & $\begin{array}{l}\text { One point is attributed in case of: } \\
\text { fan chart with the central path of inflation publication, } \\
\text { probability distribution publication, } \\
\text { risk description (qualitative), } \\
\text { alternative scenario. }\end{array}$ \\
\hline 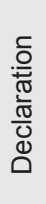 & $\begin{array}{l}\text { Information } \\
\text { on the forecast } \\
\text { importance } \\
\text { for the MPC }\end{array}$ & $\begin{array}{l}0-\text { none } \\
1 / 2-\text { not explicitly } \\
1-\text { yes }\end{array}$ & $\begin{array}{l}\text { Information on the forecast role in monetary policy. } \\
1 / 2-\text { when it is given descriptively (ex. forecast is one } \\
\text { of the inputs...). } \\
1-\text { for the declaration on the greatest forecast } \\
\text { importance or more detailed description of information } \\
\text { relevant to decision-making process. }\end{array}$ \\
\hline
\end{tabular}

and it presents the forecasts accuracy (which has the impact on their credibility).

The IFT index covers a broad context of IFT implementation. Central banks are free to draw their own solutions in this field, that is why, to enable the same way of points attribution, the detailed way of attributing points with the explanation is given in Tab. 2 .
Points attribution for decisions comparability depends on the assumption on the interest rates. It should also consider that the IFT is just a flexible rule for the monetary policy. It means that there is no formal obligation of following the message of the forecast. For many reasons the MPC may ignore the message of the forecast. This may happen when the staff owns the forecast. It means that the MPC is not engaged in the forecasting 


\section{Tab. 2: $\quad$ IFT index points' attribution rules - Part 2}

\begin{tabular}{|c|c|c|c|}
\hline & Evaluation & Possible options & How to attribute the points \\
\hline \multirow{3}{*}{ 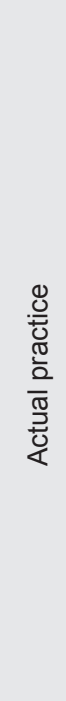 } & \begin{tabular}{|l} 
Decision \\
compatibility
\end{tabular} & $\begin{array}{l}0-\text { no } \\
1-\text { partial } \\
2-\text { yes }\end{array}$ & $\begin{array}{l}\text { Information with the highest weight. The way } \\
\text { of compatibility assessment depends on the forecast. } \\
\text { For } 1 \text { point answer: not following the message of the } \\
\text { forecast when it is accepted in terms of the target } \\
\text { definition (the MPC freedom point). } \\
\text { Detailed solution for describing points at that stage is } \\
\text { given below the table. }\end{array}$ \\
\hline & Decision timing & $\begin{array}{l}0-\text { when the forecast } \\
\text { is produced } \\
1-\text { in subsequent } \\
\text { months }\end{array}$ & $\begin{array}{l}1 \text { point is attributed for: } \\
\text { making decision when the forecast is up to date, } \\
\text { no interest rate change in the period between } \\
\text { two forecasting rounds. } \\
\text { If the decision follows the message of the forecast } \\
\text { but in subsequent months - no points } \\
0 \text { - the decision is not in line with the forecast } \\
\text { regardless of the decision timing. }\end{array}$ \\
\hline & $\begin{array}{l}\text { Forecasts } \\
\text { in decision's } \\
\text { rationale }\end{array}$ & $\begin{array}{l}0-\text { none } \\
1 / 2-\text { only CPI } \\
1-\text { communication } \\
\text { focused on the } \\
\text { forecast }\end{array}$ & $\begin{array}{l}\text { Reference to forecast in decision rationale: } \\
1 / 2 \text { if only the central path for inflation is described, } \\
1 \text { for dominating role of the forecast in } \\
\text { communication (CPI, risk, alternative scenarios). }\end{array}$ \\
\hline 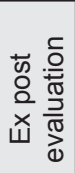 & $\begin{array}{l}\text { Past forecast } \\
\text { assessment }\end{array}$ & $\begin{array}{l}0-\text { none } \\
1 / 2-\text { one out of two } \\
\text { possibilities } \\
1-\text { both descriptions }\end{array}$ & $\begin{array}{l}1 / 2 \text { is attributed for publication of: } \\
1 \quad \text { two subsequent forecasts comparison, } \\
\text { - } \quad \text { past forecast errors analysis. }\end{array}$ \\
\hline
\end{tabular}

process. Due to extraordinary shocks, the model inadequacy may be temporarily higher in MPC opinion. The qualitative approach to data analysis may prevail during the MPC deliberations. The system of goals of the central bank embodies also the output. Inflation targeting is implemented in a flexible way. Temporarily, the output stabilization may become main concern for the central bank. Finally, the MPC may take wait and see position and observe economic situation. Therefore, there is no naive and automatic reaction of the central bank in line with the forecast. The points attribution must also consider the fact that no change of the interest rates is also a decision. Fig. 5 and 6 present the points attributing schemes. The first one refers to the conditional forecast (constant interest rate) and the second one covers endogenous interest rates case.

If considering central path of inflation it is necessary to compare it to the inflation target in the monetary policy horizon (MPH): 4 to 6 quarters ahead from the forecast starting point. CPI may vary during the monetary policy horizon. In order to calculate the IFT index it is necessary to choose the exact point of time for assessing $\mathrm{CPI} /$ target relation. Considering the beginning of $\mathrm{MPH}$ is necessary when the examination covers also expectation as it is consistent with the survey question on expectations. The second approach refers to the further part of the MPH. Comparing CPT/ target relation here means that the central bank has more time to influence economy and the economy has more time to absorb shock occurring when the forecast is produced.

The IFT index due to its division into 5 aspects makes it possible to produce an additional measurement. When ignoring actual practice aspect, it delivers the possibility to measure only transparency of the forecasting 


\section{Ekonomie}

system. Additional analysis of the decision compatibility (according to Fig. 5 and 6) alone, shows the central bank's commitment to the rule.

The IFT index offers the opportunity to crosscountry and over-time comparison. It delivers consistent framework of IFT implementation analysis. It is a useful tool of verification of the relationships between IFT implementation and central bank's effectiveness and credibility or its ability to influence expectations of consumers, business and experts. It makes it possible to

\section{Tab. 3: Sample description}

\begin{tabular}{l|c|c}
\multicolumn{1}{c|}{ Feature } & BoE & CNB \\
\hline Inflation targeting introduction & $\begin{array}{c}1992 \text { (since 1998 independence } \\
\text { in decisions on interest rates) }\end{array}$ & 1998 \\
\hline First forecast publication & January 1998 & April 2001 \\
\hline Research period & Jan 1998 - Dec 2014 & Apr 2001 - Dec 2014 \\
\hline Interest rate assumption & $\begin{array}{c}\text { CIR, ME, both are published, ME } \\
\text { as the first one since Aug 2004 }\end{array}$ & CIR, since July 2002 endogenous \\
\hline Number of forecast & 68 & 136 \\
\hline Number of decisions & 203 & \\
\hline
\end{tabular}

Source: own

Tab. 4: Mean results on IFT index

\begin{tabular}{l|c|c}
\multicolumn{1}{c|}{ Feature } & BoE & CNB \\
\hline Mean IFT index & $9.38(67 \%)$ & $11.85(85 \%)$ \\
\hline IFT $\sigma$ & 1.1 & 1.6 \\
\hline Mean transparency & $7.36(74 \%)$ & $8.27(83 \%)$ \\
\hline Decisions compatibility & $0.84(42 \%)$ & $1.80(90 \%)$ \\
\hline
\end{tabular}

Source: own

compare the decision-making procedures and the central bank's attachment to IFT. Thus, it offers the possibility for further research.

\section{Possible Implementation of the IFT Index}

The final section presents briefly the IFT index for two central banks: the Bank of England (BoE) and the Czech National Bank (CNB). They are both inflation targeters with quite a long history of inflation forecast implementation. The sample is described in Tab. 3. Both central banks refer to the forecast in the monetary policy. They use different interest rate assumptions.

Tab. 4 presents mean values of the index for both countries. The CNB was more consistent in IFT implementation with the mean index value of $85 \%$. It also outperforms the BoE on the field of forecasting system transparency. The difference in decisions' compatibility between the central banks' is remarkable: according to the methodology presented in section 3 , the BoE decisions covered IFT logic only in $42 \%$ in comparison to $90 \%$ in the case of the CNB.

Fig. 7 presents the evolution of the IFT index of the BoE during the research period, Fig. 8 - IFT index for the CNB. Fig. 7 does not capture any substantial change in IFT implementation. Its fluctuations are due mainly to decisions' compatibility or non-compatibility with the forecast and irregular publication of additional information. Fig. 8 captures remarkable institutional change in inflation forecast targeting. At the beginning of 2008 


\section{BoE IFT index}

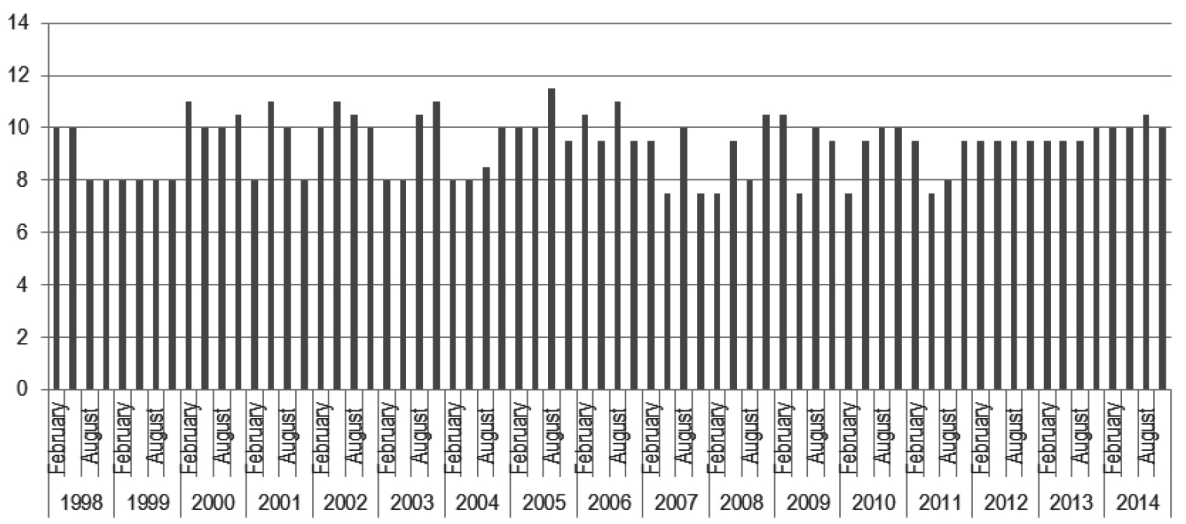

\section{BoE IFT index}

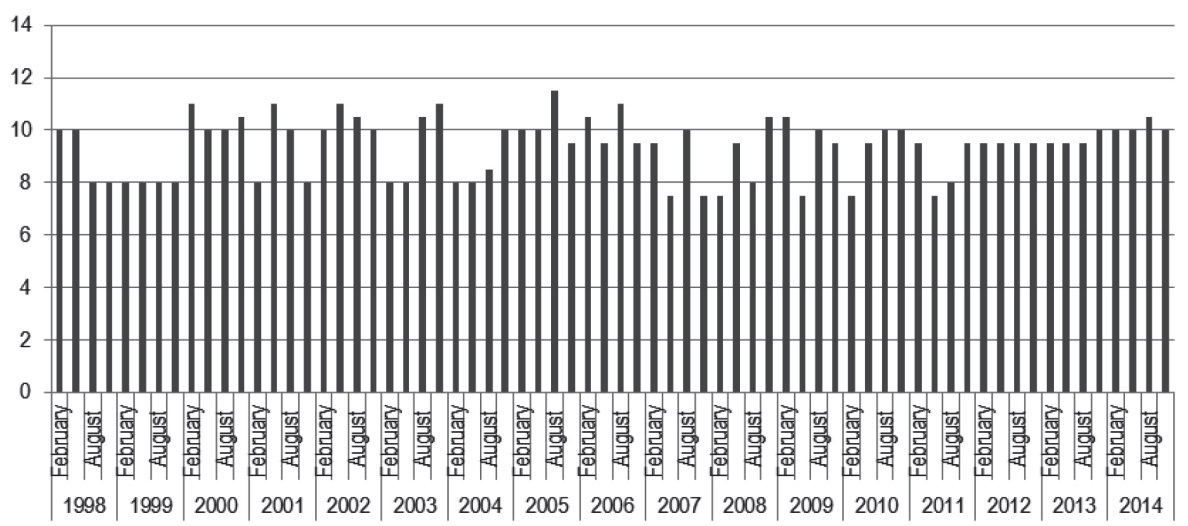


the CNB switched to DSGE model (Dynamic Stochastic General Equilibrium Model) at the same time revealing numerically policy path. The enhanced transparency (covering also risk description) resulted in higher IFT index.

The Bank of England used the forecast in the research period in a similar way. The level of IFT was just in line with its declaration on the forecast importance in the monetary policy. The BoE did not switch to interest rates endogenisation. Its communication after the MPC meeting covered the message of the forecast, however, the forecast never gained a central position in the decision explanation.

The CNB commitment to IFT was really strong. The central bank followed the message of the forecast even in the most turbulent period of financial crisis eruption in Europe. Its attitude is confirmed by the analysis of the point attribution to the timing. The CNB made decisions on the interest change (if such a change was necessary) just after producing the forecast. It did not take wait and see position. The CNB communication on the decision also focused on the forecast. Not only was the central path of inflation and policy path presented but also balance of risk. During the MPC meetings in the months in which there was no forecast, the MPC discussion focused on the assumption divergence from the starting point level and its possible impact on the central path for inflation.

\section{Conclusions}

The paper presents a conceptual framework of the analysis and measurement of inflation forecast targeting. No consistent IFT index has been presented in the literature up to now. The need for such a measurement is obvious as according to the modern monetary theory, monetary policy needs to be forward-looking. The best way to implement forward-lookingness is the reference to the forecast in the monetary policy. The central bank's forecast of inflation (and other variables) facilitates a decisionmaking process. It may even become the monetary policy intermediate target, at least implicitly (without such a declaration). It also draws the framework for the central banks discussion. On the other hand, publishing the forecast and information on forecasting system may enhance the central bank's impact on expectations.
The IFT index covers all aspect of the forecast use. However, it is possible that after some time additional questions will be needed. The first proposal on measuring central bank transparency covered goals and decisions publication. Nowadays this seems obvious. The policy path publication differentiates the central banks. The next step in transparency is also possible. The example is publication of bilateral exchange rate forecast done by the CNB since 2009. The index may evolve with the evolution of the monetary policy.

The researchers have always searched for tools for verification relations existence. IFT index is such a tool. It is easily applicable as the way of point attribution is consistent with the practice of modern central banks. Up to now the index has been used to compare the level of consistency in the inflation forecast targeting and the interdependences of the forecast and inflation expectations of consumers (Szyszko, 2015). Measurement of the IFT requires the reading of Inflation Reports (or equivalent documents) and central bank's statements. It draws a broader context for monetary policy and its implementation in the central bank covered by the examination.

The need of IFT index elaboration is obvious also in the light of the on-going discussion on the central bank's options for signaling its intentions. Various versions of forward guidance are discussed including quantitative forward guidance which takes form of policy path publication in a numerical way (Svensson, 2015; Woodford, 2013). This paper opens the discussion not on the need of IFT measurement but on possible improvements of the index.

The contribution presents the results of research financed by the National Science Center: Interdependences of Inflation Forecasts and Inflation Expectations of Market Participants. Implications for the Central Banks contract No.: 2011/03/B/HS4/03705.

\section{References}

Bajalan, S., Raei, R., \& Tehrani, R. (2012). Development of an Index for Measuring the Central Bank's Transparency. Arguemnta Oeconomica, 28(1), 14-40.

Bernanke, B., Laubach, T., Mishkin, F. S., \& Posen, A. S. (2001). Inflation Targeting: Lessons from the international Experience. Princeton: Princeton University Press. 
Bini-Smaghi, L., \& Gros, D. (2001). Is the ECB Sufficiently Accountable and Transparent? [European Network of Economic Policy Research Institutes Working Paper No. 7].

Brzoza-Brzezina, M., \& Kot, A. (2008). The Relativity Theory Revised: Is Publishing Interest Rates Forecast Really so Valuable? [National Bank of Poland Working Papers No. 052].

Chortareas, G., Stasavage, D., \& Sterne, G. (2002). Does it Pay to Be Transparent? International Evidence form Central Bank Forecasts. The Federal Reserve Bank of St. Louis Review, July/August, 99-118.

Crowe, C., \& Meade, E. (2008). Central Bank Independence and Transparency: Evolution and Effectiveness. European Journal of Political Economy, 24(4), 763-777. doi:10.1016/j.ejpoleco.2008.06.004.

Dincer, N. N., \& Eichengreen, B. (2014). Central Bank Transparency and Independence: Updates and New Measures. International Journal of Central Banking, 10(1), 189-253.

Dincer, N. N., \& Eichengreen, B. (2007). Central Bank Transparency: Why, Where, and with What Effects? [National Bureau of Economic Research Working Paper 13003]. doi:10.3386/w13003.

Ehrmann, M., \& Sondermann, D. (2009). The Reception of Public Signals on the Financial Markets. What if Central Bank Communication Become Stale? [European Central Bank Working Paper Series, Working Paper No. 1077]. pp. 16-21. doi:10.2139/ssrn. 1744825.

Eijffinger, S. C., \& Geraats, P. M. (2005). How Transparent Are Central Banks? [Cambridge Working Papers in Economic No. 0411]. doi:10.1016/j.ejpoleco.2005.09.013.

Eusepi, S., \& Preston B. (2010). Central Bank Communication and Expectations Stabilization. American Economic Journal: Macroeconomics, 2(3), 235-271. doi:10.1257/ mac.2.3.235.

Fry, M., Julius, D., Mahadeva, L., Roger, S., \& Sterne, G. (2000). Key Issues in the Choice of a Monetary Policy Framework. In L. Mahadeva, \& G. Sterne (Eds.), Monetary Policy Frameworks in a Global Context (pp. 1-16). London: Routledge.

Fracasso, A., Genberg, H., \& Wyplosz, C. (2003). How Do Central Banks Write? An Evaluation of Inflation Targeting Central Banks. Geneva Reports on the World Economy Special Report 2. Geneva: International Center for Monetary and Banking Studies. Centre for
Economic Policy Research.

Galí, J. (2008). Monetary Policy, Inflation, and the Business Cycle, An Introduction to the New Keynesian Framework. Princeton: Princeton University Press.

Geraats, P. M. (2001). Why Adopt Transparency? The Publication of the Central Bank Forecast. [European Central Bank Working Paper Series Working Paper No. 41].

Geraats, P. M. (1999). Transparency and Reputation: Should the ECB Publish its Inflation forecast? Conference on Monetary Policy Making under Uncertainty. Frankfurt am Main: European Central Bank, Center for Financial Studies.

Goodfriend, M., \& King, R. G. (1997). The New Neoclassical Synthesis and the Role of Monetary Policy. National Bureau of Economic Research Annual, 1997(12), 231-296. doi:10.2307/3585232.

Goodhard, C. A. E., \& Bin Lim, W. (2011). Interest Rate Forecast: a Pathology. International Journal of Central Banking, 2(7), 135-171.

Faust, J., \& Svensson, L. E. O. (2001). Transparency and Credibility: Monetary Policy with Unobservable Goals. International Economic Review, 42(2), 369-397. doi:10.1111/1468-2354.00114.

Kumar, S., Afrouzi, H., Coibion, O., \& Gorodnichenko, Y. (2015). Inflation Targeting Does not Anchor Inflation Expectations. Evidence from Firms in New Zealand. [NBER Working Paper No. 21814]. doi:10.3386/ w21814.

Leitemo, K. (2006). Open-Economy Inflation-Forecast Targeting. German Economic Review, 7(1), 35-64. doi:10.1111/j.14680475.2006.00146.x.

Mishkin, F. S. (2004). Can Central Bank Transparency Go too Far? [NBER Working Paper No. 10829]. doi:10.3386/w10829.

Siklos, P. L. (2002). The Changing Face of Central Banking. Evolutionary Trends Since World War II. Cambridge (NY): Cambridge University Press. doi:10.1017/ CBO9780511606427.

Siklos, P. L. (2010). Central Bank Transparency: Another Look. [Center for Applied Macroeconomic Analysis Working Paper 23]. doi:10.2139/ssrn.1668213.

Skořepa, M., \& Kotlán, V. (2003). Assessing Future Inflation in Inflation Targeting: Forecasts or Simulations. In Monetary Policy in Changing 


\section{Ekonomie}

Environment. Bank for International Settlements Paper 19, 147-157.

Svensson, L. E. O. (1997). Inflation Forecast Targeting: Implementing and Monitoring Inflation Targets. European Economic Review, 41(6), 1111-1146. doi:10.1016/S0014-2921(96)00055-4.

Svensson, L. E. O. (1999). Inflation Targeting as a Monetary Policy Rule. Journal of Monetary Economics, 43(3), 607-654. doi:10.1016/S0304-3932(99)00007-0.

Svensson, L. E. O. (2015). Forward Guidance. International Journal of Central Banking, 11(S1), 19-64.

Svensson, L. E. O. (2003). What Is Wrong with Taylor Rules? Using Judgment in Monetary Policy through Targeting Rules. Journal of Economic Literature, 41(2), 426-477. doi:10.1257/.41.2.426.

Strohsal, T., \& Winkelman, L. (2015). Assessing the anchoring of inflation expectations. Journal of International Money and Finance, 50, 33-48. doi:10.1016/j. jimonfin.2014.09.001.

Szyszko, M. (2013). The Interdependences of Central Bank's Forecasts and Inflation Expectations of Consumers. Bank $i$ Kredyt, 44(1), 33-66.

Szyszko, M. (2015). Inflation Forecast versus Shaping Inflation Expectations. Comparative Analysis. Comparative Economic Research, 18(4), 139-156. doi.10.1515/cer2015-0033.

Taylor, J. B. (1993). Discretion versus Policy Rules in Practice. Carnegie-Rochester Conference Series on Public Policy, 39. 195214. doi:10.1016/0167-2231(93)90009-L.
Cruijsen van der, C. A. B., \& Eijffinger, S. C. W. (2010). The Economic Impact of Central Bank Transparency: A Survey. In P. Siklos, M. Bohl, \& M. Wohar (Eds.), Challenges in Central Banking: The Current Institutional Environment and Forces Affecting Monetary Policy (pp. 261319). New York: Cambridge University Press.

Winkler, B. (2000). Which Kind of Transparency? On the Need for Clarity in Monetary Policy - Making. [European Central Bank Working Paper Series, WP No. 26].

Woodford, M. (2012). The Case for Forecast Targeting as a Monetary Policy Strategy. In E. F. Koening, R. Leeson, \& G. A. Kahn (Eds.), The Taylor Rule and the Transformation of Monetary Policy (pp. 185-234). Stanford: Hoover Institution Press, Stanford University.

Woodford, M. (2003). Interest and Prices. Foundations of Theory of Monetary Policy. Princeton: Princeton University Press.

Woodford, M. (2013). Forward Guidance by Inflation Targeting Central Banks. In Two Decades of Inflation Targeting: Main Lessons and Remaining Challenges, Sveriges Riksbank, June 3. Retrieved July 10, 2015 form http:// www.columbia.edu/ mw2230/RiksbankIT.pdf.

Magdalena Szyszko, Ph.D. WSB Poznań School of Banking Finance and Banking Faculty Institute of Economics and Social Sciences magdalena.szyszko@wsb.poznan.pl 


\section{Abstract}

\section{MEASURMENET OF INFLATION FORECAST TARGETING. A PROPOSAL OF METHODOLOGICAL SOLUTION}

\section{Magdalena Szyszko}

The paper offers a methodological solution to measuring inflation forecast targeting (IFT). IFT is a central bank's procedure which consists in: producing its own inflation forecast, revealing its results and making interest rates decisions on the basis of the forecast. Inflation forecast targeting is implemented, to some extent, by any central bank implementing inflation targeting framework. It facilitates the forward-looking attitude of the central banker. This forward-lookingness facilitates the expectations shaping and goals achievement. The literature on IFT is broad but it does not cover a concise framework for IFT analysis and measurement. The following contribution fills in this gap. It presents the IFT index. The idea of its elaboration is in line with any monetary policy qualitative aspects measurement: 5 aspects of IFT are distinguished, each of which having a system of points attribution described. These aspects are: forecasting methodology, declaration on the forecast role in the monetary policy, forecast publication, actual central bank's practice and ex post forecast evaluation. Actual central bank's practice covers the assessment of the central bank's decision compatibility with the message of the forecast. The multivariate scheme of assessment which considers central bank's flexibility in the decision making process - guaranteed by the framework of the inflation targeting - is elaborated. The other IFT aspects' evaluations consist in the analysis of the information revealed. The IFT can be divided into two sub indices: one covering only the forecasting system transparency and the other one - for decisions compatibility check. The IFT index and sub-indices are universal in the sense of considering the IFT broadly on the basis of various central bank's practice. The index can be used to cross-country and over time comparison - such an example is also presented in the paper. It also makes it possible to verify the hypotheses on the central banks' consistency in implementing IFT - measured by IFT index - and the central banks' performance.

Key Words: Inflation forecast, inflation forecast targeting, inflation forecast targeting measurement.

JEL Classification: E58, E52, B410.

DOI: 10.15240/tul/001/2017-4-001 